\title{
COVID-19 and the Rise of Crime in Developing Countries
}

\author{
Tobi Achudume
}

American Graduate School in Paris (4, rue de Chevreuse, 75006, Paris)

Corresponding author: tachudume@gmail.com

Received: 31, March, 2021

Accepted: 07, April, 2021

Published: 01, May 2021

\begin{abstract}
It is not news that the world was on a stand still for about a year, and now, we operate in a new normal. A good number of research has been carried out on this topic. Where there has been a discord is how the pandemic affected more things than just the economy of states and the health sector. In many countries of the world, as a result of the virus and the lockdown that followed in the international community, there was a big rise in crime rates and domestic violence in states. This article explores the rise of crime in Nigeria and how this affected the country even in a pandemic. This research adopts the use of case study method to see the rise in crime and how it happened in a pandemic.
\end{abstract}

Keywords: Pandemic, Crime, Developing countries

\section{Introduction}

A lot of research has been carried out on the detection and spread of the Coronavirus from Wuhan China. The coronavirus is a communicable respiratory disease that spreads from one person to another through infected droplets of liquid. The virus spread so quickly that we had to be retrained on how to wash our hands, and isolation became the new normal. This article aims to add knowledge to the existing study on the virus and its effects. It critically analyses Nigeria's response to the pandemic and the readiness of the health sector for such a crisis. The article also expounds on how the pandemic and restrictions on movement caused a spike in the crime rates in Nigeria.

\section{Nigeria's Response to the Pandemic}

At the discovery of the pandemic, the virus was downplayed by several countries of the world though people had started losing their lives. Major european countries suffered terribly for this mistake. For example, Italy experienced clusters of cases on 21 February and recorded its first death on 22 February 2020 (Ravizza, 2020). By March of 2020, Italy had recorded over 500,000 cases, yet Nigeria still had its borders and airports opened for international travels. This is in spite of the fact that the World Health Organisation had declared the coronavirus outbreak a Public Health Emergency of International Concern (PHEIC) on January 30, 2020 (WHO, 2020).

Though Nigeria's response to the pandemic was delayed, several measures have been taken by the Nigerian Federal government and many state governments to curb the spread of the virus in the country. On the 29th March 2019, the first lockdown was imposed in the country by the government on some major cities, and it included a complete restriction of movement in some parts of the country. These states included Abuja, Lagos, Ogun state. The second lockdown was imposed on more states though in a relaxed form. Several states in the country however modified this lockdown to what was assumed to be best for their states. For example, Ogun state, governed by Prince Dapo Abiodun first imposed restrictions during the workdays with freedom of movement in the weekend. But this measure was refined to impose the lockdown on alternate days.

The first lockdown was for an initial period of fourteen days though it was extended for a longer duration. During this lockdown, the president of the country, Mohammadu Buhari imposed a direct "cessation of all movements in Lagos and the Federal Capital Territory, Abuja". In his words, the "restriction will also apply to Ogun State due to its close proximity to Lagos and heavy traffic between the two states" (Olanrewaju, 2020). The president ordered a ban on all forms of social and economic activities and gatherings in this period. At this time of the imposition of the lockdown, Nigeria had recorded 111 confirmed cases (The Nigerian Centre for Disease Control, 2020).

In ensuring that the laws of the restrictions were followed, the security agencies which include the military and police were employed. There was an increase in interagency cooperation between the security agencies, and this is one of the weaknesses of security agencies in Nigeria (Asimi, 2020). Though this was present, the pandemic only exposed more human rights issues, corruption and economic challenges that the citizens of the country 
face on a daily basis. Though these were already present, the pandemic emphasised the dangers and effects on the people.

\section{The Uselessness of Restrictions}

On Sunday 29th of March 2020, the Nigerian president, Muhammadu Buhari announced a lockdown in major states and cities of the country that were worst hit by the coronavirus. While addressing the nation, the President banned all economic and social gatherings in the Federal Capital, Abuja, Lagos and Ogun state. This restriction on movement was set for an initial period of 14 days. It is opined that there were two objectives for the drastic lockdown- "first, to slow down the spread of the virus across the country, and second, to buy time for the health system to increase its preparedness" (Dan-Nwafor, 2021). Yet, with the restrictions on movement, the virus had already spread as most states recorded their first cases in this period.

\section{Human Rights Violations}

With the economic situation of the country, especially at the crux of the pandemic in Nigeria, the imposition of the lockdown had been rendered useless. However, to maintain this, the government employed the use of security forces and this included both the police and military. With the imposition of a lockdown in the major cities of the country, the directives also empowered the security agencies to ensure the compliance of these restrictions. Shortly after the lockdown was imposed, in April, the National Human Right Commission reported that security agents in the country had killed about 18 people in the first two weeks of the lockdown which at the time was more than the fatalities of COVID-19 in the country (NHRC, 2020). In the report, it was stated that these deaths were caused by the excessive use of force to ensure that the lockdown was observed.

\section{Increase in Organized Crime}

In addition to the violations of human rights is the rise in organised crime in the country. Research shows that despite the lockdown, drug traffickers still continued with their operations (NAN, 2020). Security agents turned checkpoints into opportunities to extort money from the citizens who had to make an income daily (Asimi, 2020). For citizens of the country who are low income earners, the pandemic was difficult for them because the majority of these people survive on the income that they make per day. This income is what is used to sustain the household for the day. During the pandemic, with the imposition of a lockdown on daily movements, these persons could not make the income that they need and had to look for alternatives. In Ogun state, for example, there were several reports of robbery in neighbourhoods and business places. This put people at danger and obstructed the freedom and peace they enjoyed in their homes.

A major part of the population of Nigeria are less privileged and survive daily from the profits they make daily. With the drastic implementation of a lockdown, there was significant economic and social cost. Prior to the spread of the virus and the implementation of the lockdown in the country, researchers and security experts had predicted that there will be a rise in crime rates looking at the responses in other countries in the international community (Olanrewaju, 2020). There was therefore an increase in crime and domestic violence in this period.

According to former Department of State Services (DSS) boss, Dennis Amachree, the fallouts of the lockdown especially in the major cities in the country indicated the spike in criminal activities during the pandemic (Odita, 2020). This is because criminals will take advantage of the inadequate number of security forces and law enforcement officers and carry out violent crimes. As a result of the economic impact of the pandemic on the country, there has also been a rise in unemployment rates as a lot of people had been forced to shut down their businesses and others had to cut down staff. with the desperation to feed themselves and their families comes an increase in crime rates in the country (Odita, 2020).

As a response to the spread of the virus, especially in the prisons that already operated at 150 percent over their capacity, the Nigerian government ordered the release of prisoners. Abubakar Malami, the Attorney General of the Federation and Minister of Justice, stated that Nigeria's initiatives to curb the spread of the virus "led to the release of the inmates while simultaneously reducing the instances of unnecessary test" (Fairtrials, 2020; Qureshi, et al, 2020). Amachree on the other hand opines that though the release of the criminals will curb the spread of COVID19 in the prisons and the country, there is a high probability that these criminals will regroup to form gangs.

Why this contributed to the rise of crime rates is that the Nigerian prisons are not correctional facilities, the inmates therefore tend to acquire more dangerous habits before they are released.

The police and military have been accused of profiting from the lockdown by collecting bribes from motorists in exchange for free passage at checkpoints (Asimi, 2020). This was further encouraged because of the level of corruption present in the law enforcement agencies.

There was also an increase in cybercrime with people selling fake medical products online (Asimi, 2020). With the need to purchase medical equipment by many countries, many fraudsters took advantage of the urgency and scammed medical personnels. Due to the pandemic and the government's response, there was a spike in the number of cyberattacks. These attacks were carried out via misinformation, impersonation and phishing with no notice (Ogbonnaya, 2020).

Several cyberattackers were arrested during the pandemic. In September 2020, EFCC arrested a cyber criminal syndicate of 13 suspected members for defrauding victims of millions of naira (Ogbonnaya, 2020). In response to this, banks in Nigeria have taken extra measures to prevent this, one of which is sending messages to customers to be careful of online transactions (CBN, 2020).

\section{Conclusion}

The COVID-19 pandemic exposed the rate at which crime can escalate in developing countries with poor governance and corrupt leaders. The percentage of persons with health insurance in such countries are on the lower spectrum of the scales. This is coupled with the fact that over half of the citizens in the country live in poverty and cannot afford to miss a day of work.

Corruption in the security agencies has proven difficult to curtail because citizens find it difficult to report bribery cases to these agencies. According to a 2019 survey, only 3.6 percent of citizens reported a case of bribery to an official institution out of which 51 percent received no follow up on the case. To reduce bribery in the country, citizens should be able to report misconduct and misdemeanour of security officers when the crime is committed and from their homes. To go further in curbing these, these institutions should ensure that these cases when reported are properly dealt with and followed up, and feedback is given to the 
citizens who reported the crime. With this, there will be a level of trust between the citizens of the country and the security agencies and institutions.

\section{Bibliography}

[1] African Union. "COVID-19 Daily Updates." Africa CDC. Last modified July 6, 2020. https://africacdc.org/covid-19/.

[2] Asimi, Samuel. "In Nigeria, COVID-19 Brings Home the Need for Effective Criminal...." Transparency.org. Last modified June $5,2020$. https://www.transparency.org/en/blog/in-nigeria-covid19-brings-home-the-need-for-effective-criminal-justicecomplaint-channels.

[3] Central Bank of Nigeria. Alert! Beware of COVID-19 Cyberattacks. Fraud. Nigeria: CBN, 2020.

[4] Dan-Nwafor, Chioma. "Nigeria's Public Health Response to the COVID-19 Pandemic: January to May 2020." Journal of Global Health. Last modified March 29 , 2021. https://www.jogh.org/documents/issue202002/jogh-10020399.htm.

[5] Fairtrials. "Short Update: Nigeria Released 7,813 Prisoners Amid COVID-19 Outbreak Within Prisons." Fair Trials. Last modified July 16, 2020. https://www.fairtrials.org/news/short-update-nigeriareleased-7813-prisoners-amid-covid-19-outbreak-withinprisons.

[6] NAN. "NDLEA Nabs Suspected Cannabis Trafficker in Benin." The Guardian Nigeria News - Nigeria and World News. Last modified May 5, 2020. https://guardian.ng/news/ndlea-nabs-suspected-cannabistrafficker-in-benin/.
[7] NHRC. "National Human Rights Commission Press Release on COVID-19 enforcement so far report on incidents of violation of Human Rights." National Human Rights Commission - National Human Rights Commission. Last modified April 15, 2020. https://www.nigeriarights.gov.ng/nhrc-media/pressrelease/100-national-human-rights-commission-pressrelease-on-covid-19-enforcement-so-far-report-onincidents-of-violation-of-human-rights.html.

[8] Odita, Sunday. "'Why Crime Rate May Rise After COVID-19'." The Guardian Nigeria News - Nigeria and World News. Last modified April 21, 2020. https://guardian.ng/news/why-crime-rate-may-rise-aftercovid-19/.

[9] Ogbonnaya, Maurice. "Cybercrime in Nigeria Demands Public-private Action." ISS Africa. Last modified October 19, 2020. https://issafrica.org/isstoday/cybercrime-in-nigeria-demands-public-privateaction.

[10] Olanrewaju, Kola. "COVID-19: Nigeria Announces Lockdown of Major Cities." Anadolu Ajans1. Last modified March 2020. https://www.aa.com.tr/en/africa/covid-19-nigeriaannounces-lockdown-of-major-cities/1784358.

[11] Qureshi, Asma, Ima Kashim, Similolu Akintorin, Larissa Unruh, Sadhana Dharmapuri, and Kenneth Soyemi. "COVID-19 and the Nigerian correctional service: need for structured data." Pan African Medical Journal 37 (2020). doi:10.11604/pamj.supp.2020.37.1.25370.

[12] Ravizza, Simona. "Coronavirus, Due Casi a Milano." Corriere Della Sera. Last modified February 22, 2020. https://www.corriere.it/cronache/20_febbraio_22/corona virus-italia-nuovi-contagi-lombardia-veneto-245e $72 \mathrm{~d} 4$ 5540-11ea-8418-2150c9ca483e.shtml. 